\title{
Editorial: the EJMS starts being published by Emerald
}

\author{
Tiago Cardão-Pito
ISEG (Lisbon School of Economics and Management), \\ Tiago Cardão-Pito
ISEG (Lisbon School of Economics and Management), \\ Universidade de Lisboa, Lisbon, Portugal
}

Uhiveridade de Lisboa, Lisbon, Portugal

Received 17 September 2020 Accepted 17 September 2020

This issue is published during a difficult global pandemic, which has had substantial effects upon our human societies. I regret all the suffering and lives lost due to the Covid-19 virus. Knowing no borders, and unconstrained by rhetoric, politics, or social media, this virus has revealed itself an insidious enemy to humankind. We have to believe that, sooner or later, we will defeat it, either through natural immunity or with artificial immunity, via vaccines and medicines. However, this will not occur until the microbe has caused havoc around the globe, with some severe social and economic consequences which are yet to be fully comprehended.

Most organisations and management activities have been affected. Universities have been particularly impacted. The traditional system of face-to-face lecturing was entirely disrupted during the middle of the academic year. To adapt, universities had to put into operation digital technologies, whose use had not been predicted just a few months before. Research, likewise, may have been constrained, as scientific conferences were suspended or replaced by internet-based ones. All of a sudden, researchers were told to operate from home, away from universities and their peers, many of whom were already adapting to a digital revolution at a fast-track pace. Here at the Journal, we are open to receiving submissions on these above-mentioned topics.

However, in the middle of this extraordinary scenario, we have some very good news regarding the EJMS. As the reader must have noticed, the Journal is now being published by Emerald. This important scientific publisher has established a partnership with us at ISEG, Universidade de Lisboa [University of Lisbon]. Although ISEG will maintain the responsibility for the Editorial Policy, Emerald will bring about many important changes to the Journal, with several improvements, such as the web page, the manuscript submission system, distribution, promotion channels, and an invaluable expertise in publication affairs.

This association with Emerald thus represents the next step in the life of this Journal, which is already celebrating its 27th year of uninterrupted publication. Founded in 1993, as "Estudos de Gestão", it later changed its name to "The Portuguese Journal of Management Studies". In 2015, the Journal endorsed a more international outlook, and modified its name to "The European Journal of Management Studies". Nonetheless, ever since its inception, the Journal has been a generalist journal in Management, which is interested in publishing articles in the different areas of Management, including strategy, marketing, human resources, organisational behaviour, operations and logistics, finance, accounting,

(C) Tiago Cardão-Pito. Published in European Journal of Management Studies. Published by Emerald Publishing Limited. This article is published under the Creative Commons Attribution (CC BY 4.0) licence. Anyone may reproduce, distribute, translate and create derivative works of this article (for both commercial and non-commercial purposes), subject to full attribution to the original publication and authors. The full terms of this licence may be seen at http://creativecommons.org/licences/by/4.0/legalcode 
EJMS

25,1

management control, taxation, information systems for management, entrepreneurship, economic sociology, and international management.

As noted in a previous Editorial (Cardao-Pito, 2019), the Journal has constituted a team of Associate Editors, all of whom have skills in different sub-areas of Management, who help us coordinate the Journal and evaluate submissions. We meet on a regular basis. Furthermore, all research articles published in the Journal undergo a blind-peer review process where at least two reviewers are involved. We aim to be a rigorous scientific journal in terms of argumentation and methodology, which is nevertheless pluralist and interdisciplinary in terms of its contents, in alignment with ISEG's culture of pluralism and interdisciplinarity. We are not constrained by specific local systems of validity as paradigms or epistemes, but rather encourage new ideas, methods, analyses, and arguments. We also welcome reviews about interesting books which are aligned with the scope of the Journal. Despite the ongoing pandemic which we all have to endure, we are pleased to be able to share with you the excellent news of our association with Emerald.

\section{Reference}

Cardao-Pito, T. (2019), "Changes to the Board of the Journal", European Journal of Management Studies, Vol. 24 No. 1, p. 1.

\section{Corresponding author}

Tiago Cardão-Pito can be contacted at: tcp@iseg.ulisboa.pt

For instructions on how to order reprints of this article, please visit our website: 